\title{
Exterior Features of Siberian Sturgeon Underyearlings when Applying Bs 225 Microbiological Preparation
}

\author{
Grigoriy Nozdrin, Irina Moruzi, Yelena Pishchenko, Angela Ivanova, Sophia Nurutdinova* and \\ Yekaterina Startseva \\ Novosibirsk State Agrarian University, Novosibirsk, Russia; \\ moryzi@ngs.ru
}

\begin{abstract}
BS 225 impact on the exterior features of the Acipenseridae has been studied. BS 225 is a microbiological preparation containing Bacilus Siamensisas as a basis. The efficiency of its application in sturgeon aquaculture is demonstrated by a scientific and commercial experiment. Each test group of sturgeon underyearlings had its own feeding schedule at a definite dosage. It was proved experimentally that the dosage determines exterior features and essential biological parameters, such as Fulton's condition factor, fineness ratio, scale factor, thickness ratio and mass buildup. The obtained data confirm that microbiological preparation initiates sturgeon growth, is beneficial for fish exterior features and improves winter resistance, environmental resistance and survivability of fish.
\end{abstract}

Keywords: BS 225, Fineness Ratio, Fulton's Condition Factor, Girth Factor, Probiotics, Sturgeon Aquaculture, Thickness Ratio, Underyearlings

\section{Introduction}

Fish husbandry is one of the most promising sectors of agriculture. However, according to Aditya KesarcodiWatson from the Cawthron Institute, to solve many problems in fish aquaculture, such as the potential pathogenic microflora development, frequent outbreaks of infectious diseases, the low survival rate of fish juvenile, low immunity in the fingerlings, search for alternatives to antibiotics, determines an ever-increasing demand for new aquaculture products. In the modern fish farming for the prevention and treatment of diseases of various etiologies there is an actively developing trend to use probiotics ${ }^{1}$.

Use of probiotics is one of the most advanced, safe and effective ways to prevent animal and fish diseases and increase fish survivability ${ }^{2-6}$.

Modern science considers the normal microflora of the body as an independent system, which feeds, cleans and protects the body. In its role in maintaining the homeostasis the intestinal microflora is not inferior to any other vital organs. All of this allows considering it as an independent system ${ }^{7-9}$.

The biological balance between a living organism and microbial flora which has developed in the course of evolution is a kind of indicator of the microorganism state, its reaction to various pathological processes in the body and any changes in the environment. The intestinal microflora has enormous metabolic potential and is capable of carrying out a lot of biochemical processes, contributing to the physiology of the organism. Owing to the fermentation activity (amylolytic, proteolytic, cellulosolytic, etc.) microflora is able to synthesize many biologically active substances: organic acids, alcohols, lipids, vitamins, especially of B group, which play an important role in the host organism sustenance. About $20 \%$ of the nutrients coming to the intestine, and $10 \%$ of the energy are consumed to feed microflora ${ }^{10-13}$.

\footnotetext{
${ }^{*}$ Author for correspondence
} 
Probiotics are intended for treatment and prevention of gastrointestinal diseases of bacterial and viral etiology, they also exert a positive effect on fish-farming and biological indicators for growing fish in aquaculture ${ }^{14}$.

The leading position in the world in the field of warm-water aquaculture is taken by China, Thailand, the northern countries of Europe, Latin American countries. Application of probiotics (BioGut Aqua, Sukahan, Bioclean Aqua Plus, Saki-Hikari Balance) also became a frequent practice in these countries.

Application of probiotics and their fish health effect is understudied up to date. Our work is aimed at studying BS 225 microbiological preparation impact on the exterior features of Siberian sturgeon underyearlings.

\section{Materials and Methods}

A scientific and commercial experiment was carried out at the LLC "Novosibirsk Fish Processing Plant" to study the impact of BS 225 Bacilus Siamensis-based microbiological preparation on the fish exterior features. Three test groups and one control group of Siberian Sturgeon (Acipenser baerii) underyearlings were formed to implement the objectives and tasks of the experiment. Prior to apply the preparation 10 fish specimens from each pool were weighed in electronic scales and measured to determine fish length, maximum height, the largest girth, and maximum thickness. On the basis of the obtained data three test groups and one control group were formed. Underyearlings of the $1^{\text {st }}, 2^{\text {nd }}$ and $3^{\mathrm{d}}$ test and control groups were kept in 1, 3, 8 and 7 aquariums, respectively.

The experiment duration took 3 months. Before application the preparation was diluted in $100 \mathrm{ml}$ of water and mixed with feed products directly prior to fish feeding. The preparation dosage was calculated based on the average weight of the weighed fish. Check-weighing was made before the preparation application, on the $6^{\text {th }}$ day of preparation application, and also on the $16^{\text {th }}, 26^{\text {th }}$, $36^{\text {th }}, 46^{\text {th }}$ and $56^{\text {th }}$ day of the preparation application. The measurements were performed before the preparation application, on the $30^{\text {th }}$ day of preparation application, as well as on the $60^{\text {th }}$ and $90^{\text {th }}$ day of the experiment. For underyearlings of the $1^{\text {st }}$ test group the preparation was applied at a dosage of $10 \mathrm{mcl} / \mathrm{kg}$ fish mass for 5 days, followed by 10 applications at the same dosage every other day and 6 applications once per 5 days. Sturgeons of the $2^{\text {nd }}$ test group were fed with the preparation at a dosage of
$5 \mathrm{mcl} / \mathrm{kg}$ fish mass for 5 days, followed by 10 applications every other day and 3 applications once per 10 days. Fish of the $3^{\mathrm{d}}$ test group were given the preparation at a dosage $15 \mathrm{mcl} / \mathrm{kg}$ fish mass for 5 days, followed by 10 applications every other day.

The feeding schedule and food composition was common for fish of all groups. Fish were fed twice per day with sturgeon food "EFICO Sigma" of the BioMar trading company containing $60 \%$ protein, $29 \%$ lipid and $11 \%$ NFE. This feed is formulated specifically with regard to sturgeon physiological needs and consists of fish meal, soybean cake, wheat, sunflower cake, guar protein, rape oil, rape cake; it is also boosted with all necessary vitamins and key minerals.

The exterior features were studied by determining the main parameters and fish exterior factors. The following factors were determined: Fulton's condition factor, fineness ratio, girth factor, thickness ratio and mass buildup factor.

Statistical processing of the obtained data was carried out using standard software package of Microsoft Excel (2008) application.

\section{Results}

Prior to start applying the probiotic the underyearlings of the $1^{\text {st }}, 2^{\text {nd }}$ and $3^{\mathrm{d}}$ test groups and the control one had no significant difference relating to the studied parameters and factors (Tables 1-5). During application of BS 225 microbiological preparation the exterior parameters of underyearlings were changing (Tables 1-5).

Condition factor is an important biological parameter of sturgeon underyearlings' state. When studying Fulton's condition factor in dynamics, it was noted that at the beginning of the experiment in the $1^{\text {st }}$ test group this factor was equal to 0.80 ; later during the preparation application it showed increasing dynamics. In 30 days after the preparation application started it amounted to 1.56 , on the $60^{\text {th }}$ and $90^{\text {th }}$ day of the experiment it made 0.90. In the $2^{\text {nd }}$ test group Fulton's condition factor at the beginning of the experiment was 0.91 , in 30 days of the preparation application it made 1.69, in 60 days it decreased down to 0.84 , and on the $90^{\text {th }}$ day it was 0.95. In the $3^{\text {rd }}$ test group Fulton's condition factor at the beginning of the experiment was equal to 0.84 , in 30 days of the preparation application it showed increasing dynamics and made 1.83, in 60 days it decreased down 
Table 1. Fulton's condition factor for sturgeon underyearlings

\begin{tabular}{lcccc}
\hline Groups & \multicolumn{4}{c}{ Fulton's condition factor (day) Standard range 0.36-3.2 } \\
\cline { 2 - 5 } & Prior to application & $\mathbf{3 0}$ & $\mathbf{6 0}$ & $\mathbf{9 0}$ \\
\hline $1^{\text {st }}$ test group & $0.80 \pm 0.06$ & $1.56 \pm 0.15$ & $0.90 \pm 0.03$ & $0.90 \pm 0.04$ \\
$2^{\text {nd }}$ test group & $0.91 \pm 0.05$ & $1.69 \pm 0.18$ & $0.84 \pm 0.05$ & $0.95 \pm 0.06$ \\
$3^{\text {d }}$ test group & $0.84 \pm 0.05$ & $1.83 \pm 0.17$ & $0.94 \pm 0.07$ & $0.97 \pm 0.03$ \\
Control group & $0.96 \pm 0.06$ & $2.02 \pm 0.20$ & $0.96 \pm 0.04$ & $0.91 \pm 0.02$ \\
\hline
\end{tabular}

Table 2. Fineness ratio in sturgeon underyearlings

\begin{tabular}{lcccc}
\hline Groups & \multicolumn{4}{c}{ Fineness ratio (day) Standard range 3.6-7.6 } \\
\cline { 2 - 5 } & Prior to application & 30 & 60 & 90 \\
\hline $1^{\text {st }}$ test group & $6.07 \pm 0.02$ & $5.78 \pm 0.28$ & $7.31 \pm 0.42$ & $6.24 \pm 0.28$ \\
$2^{\text {nd }}$ test group & $6.05 \pm 0.02$ & $6.04 \pm 0.20$ & $6.53 \pm 0.28$ & $6.51 \pm 0.36$ \\
$3^{\text {d }}$ test group & $6.03 \pm 0.20$ & $5.96 \pm 0.36$ & $6.63 \pm 0.37$ & $6.82 \pm 2.2$ \\
Control group & $5.76 \pm 0.12$ & $5.63 \pm 0.20$ & $7.59 \pm 0.49$ & $6.98 \pm 0.29$ \\
\hline
\end{tabular}

Table 3. Girth factor in sturgeon underyearlings

\begin{tabular}{lcccc}
\hline Groups & \multicolumn{4}{c}{ Girth factor (day) Standard range 0.1-1.3 } \\
\cline { 2 - 5 } & Prior to application & 30 & 60 & 90 \\
\hline $1^{\text {st }}$ test group & $0.15 \pm 0.00$ & $0.18 \pm 0.00$ & $0.15 \pm 0.01$ & $0.16 \pm 0.01$ \\
$2^{\text {nd }}$ test group & $0.17 \pm 0.00$ & $0.19 \pm 0.00$ & $0.16 \pm 0.01$ & $0.16 \pm 0.01$ \\
$3^{\text {d }}$ test group & $0.17 \pm 0.00$ & $0.18 \pm 0.01$ & $0.16 \pm 0.01$ & $0.16 \pm 0.01$ \\
Control group & $0.18 \pm 0.00$ & $0.20 \pm 0.01$ & $0.16 \pm 0.01$ & $0.15 \pm 0.00$ \\
\hline
\end{tabular}

Table 4 Girth factor in sturgeon underyearlings

\begin{tabular}{lcccc}
\hline Groups & \multicolumn{4}{c}{ Thickness ratio (day) Standard range 0.1-0.2 } \\
\cline { 2 - 5 } & Prior to application & $\mathbf{3 0}$ & $\mathbf{6 0}$ & $\mathbf{9 0}$ \\
\hline $1^{\text {st }}$ test group & $0.16 \pm 0.00$ & $0.17 \pm 0.01$ & $0.15 \pm 0.01$ & $0.15 \pm 0.01$ \\
$2^{\text {nd }}$ test group & $0.16 \pm 0.00$ & $0.16 \pm 0.00$ & $0.15 \pm 0.01$ & $0.15 \pm 0.01$ \\
$3^{\text {d }}$ test group & $0.16 \pm 0.00$ & $0.16 \pm 0.01$ & $0.14 \pm 0.01$ & $0.14 \pm 0.00$ \\
Control group & $0.17 \pm 0.01$ & $0.18 \pm 0.01$ & $0.15 \pm 0.01$ & $0.13 \pm 0.00$ \\
\hline
\end{tabular}

Table 5 Mass buildup factor in sturgeon underyearlings

\begin{tabular}{lcccccc}
\hline Groups & \multicolumn{7}{c}{ Mass buildup factor (day) Standard range 0.1-0.15 } \\
\cline { 2 - 7 } & $\mathbf{6}$ & $\mathbf{1 6}$ & $\mathbf{2 6}$ & 36 & 46 & 56 \\
\hline $1^{\text {st }}$ test group & $0.18 \pm 0.01$ & $0.09 \pm 0.01$ & $0.33 \pm 0.01$ & $0.03 \pm 0.01$ & $0.06 \pm 0.01$ & $0.24 \pm 0.01$ \\
$2^{\text {nd }}$ test group & $0.15 \pm 0.01$ & $0.09 \pm 0.01$ & $0.36 \pm 0.01$ & $0.03 \pm 0.01$ & $0.09 \pm 0.01$ & $0.18 \pm 0.01$ \\
$3^{\text {d }}$ test group & $0.24 \pm 0.01$ & $0.09 \pm 0.01$ & $0.30 \pm 0.01$ & $0.04 \pm 0.01$ & $0.04 \pm 0.01$ & $0.12 \pm 0.01$ \\
Control group & $0.12 \pm 0.01$ & $0.1 \pm 0.01$ & $0.23 \pm 0.01$ & $0.06 \pm 0.01$ & $0.06 \pm 0.01$ & $0.12 \pm 0.01$ \\
\hline
\end{tabular}

to 0.94 , at the final stage of the experiment it was 0.97 . In the control group Fulton's condition factor before the preparation application was equal to 0.96 . On the $30^{\text {th }}$, $60^{\text {th }}$ and $90^{\text {th }}$ day of the experiment it made 2.02, 0.96 and 0.91 , respectively (Table 1 ).

Fulton's condition factor on the $90^{\text {th }}$ day in underyearlings of the $1^{\text {st }}, 2^{\text {nd }}$ and $3^{\text {rd }}$ test groups was higher than the initial data by $12.5,4.4$ and $15.4 \%$, respectively, and in the control group it was lower by $5.2 \%$.

Thus, we found out that Fulton's condition factor values of underyearlings from the test groups exceeded those of control analogs only on the $90^{\text {th }}$ day. Maximum 
values of this factor were recorded while the preparation was used at a dosage of $15 \mathrm{mcl} / \mathrm{kg}$ fish mass. It is important to consider Fulton's condition factor when determining the degree of fish winter readiness and estimating fish winter resistance. Low values of the condition factor indicate insufficient fish winter readiness. The amount of lipid deposits in fish body also characterizes food supply level and body resistance.

When analyzing the fineness ratio data obtained in dynamics, it was established that at the beginning of the experiment in the $1^{\text {st }}$ test group this ratio was equal to 6.07 ; on the $30^{\text {th }}, 60^{\text {th }}$ and $90^{\text {th }}$ day of the experiment it made $5.78,7.31$ and 6.24 , respectively.

In the $2^{\text {nd }}$ test group the fineness ratio was 6.05 at the beginning of the experiment; on the $30^{\text {th }}, 60^{\text {th }}$ and $90^{\text {th }}$ day of the experiment made $6.04,6.53$, and 6.51 , respectively.

In the $3 \mathrm{~d}$ test group fineness ratio equal to 6.03 at the beginning of the experiment was; on the $30^{\text {th }}, 60^{\text {th }}$ and $90^{\text {th }}$ day of the experiment it amounted to 5.96, 6.63 and 6.82, respectively.

In the control group fineness ratio was 5.76 at the initial stage of the experiment. On the $30^{\text {th }}, 60^{\text {th }}$ and $90^{\text {th }}$ day of the experiment it was equal to $5.63,7.59$ and 6.98 , respectively. Fineness ratio in underyearlings of the $1^{\text {st }}$, $2^{\text {nd }}$ and $3^{\text {rd }}$ test groups exceeded the control group data by $2.6,7.3$ and $5.9 \%$, respectively, on the $30^{\text {th }}$ day of the experiment (Table 2 ).

The analysis of the obtained data demonstrated that higher fineness ratio in the test fish was recorded only on the $30^{\text {th }}$ day of research. On the $60^{\text {th }}$ and $90^{\text {th }}$ day of the experiment the fineness ratio in sturgeon of the $1^{\text {st }}, 2^{\text {nd }}$ and $3^{\text {rd }}$ test groups was lower than in the control group, though the statistical data are not valid.

Fineness ratio indicates morphological features of fish development. We have not determined a significant difference of this parameter in the test and control groups. Fineness ratio in underyearlings of all test groups was within the higher limits of the standard physiological range. Therefore, the studied microbiological preparation does not adversely affect the physiological processes of the fish development. During the experiment, we did not found any abnormality in the fish development.

When studying the girth factor in dynamics it was established that at the beginning of the experiment in underyearlings of the $1^{\text {st }}$ test group this parameter was equal to 0.15 ; on the $30^{\text {th }}, 60^{\text {th }}$ and $90^{\text {th }}$ day of the experiment it made $0.18,0.15$ and 0.16 , respectively.

In the $2^{\text {nd }}$ test group the girth factor amounted to 0.17 at the beginning of the experiment; on the $30^{\text {th }}, 60^{\text {th }}$ and $90^{\text {th }}$ day of the experiment it was equal to $0.19,0.16$ and 0.16 , respectively.

In the $3^{\text {rd }}$ test group the girth factor was equal to 0.17 at the beginning of the experiment, on the $30^{\text {th }}, 60^{\text {th }}$ and $90^{\text {th }}$ day of the experiment it made $0.18,0.16$ and 0.16 , respectively.

In the control group the girth factor was 0.18 at the beginning of the experiment. On the $30^{\text {th }}, 60^{\text {th }}$ and $90^{\text {th }}$ day of the experiment it was equal to $0.20,0.16$ and 0.15 , respectively (Table 3).

With regard to this parameter, sturgeons of the $1^{\text {st }}, 2^{\text {nd }}$ and $3^{\text {rd }}$ test groups exceeded the control group analogs only on the $90^{\text {th }}$ day of the experiment. The girth factor was higher than the initial data only in the underyearlings of the $1^{\text {st }}$ test group by $6.7 \%$. In the $2^{\text {nd }}$ and $3^{\text {rd }}$ test groups and in the control groups the above factor was lower than the initial data by 5.9, 5.9 and $16.7 \%$, respectively. According to the reference data, the girth factor characterizes physiological condition, fish survivability, biological and commercial value of fish flesh. We revealed positive changes in this factor on the $90^{\text {th }}$ day, as compared to the initial data, only in the underyearlings of the $1^{\text {st }}$ test group that were given the preparation at a dosage of $10 \mathrm{mcl}$ per $\mathrm{kg}$ fish mass.

When studying the thickness ratio in dynamics, it was determined that at the beginning of the experiment in the $1^{\text {st }}$ test group this ratio was equal to 0.16 , on the $30^{\text {th }}, 60^{\text {th }}$ and $90^{\text {th }}$ day of the experiment its values were $0.17,0.15$ and 0.15 , respectively.

In the $2^{\text {nd }}$ test group the thickness ratio at the beginning of the experiment amounted to 0.16 , on the $30^{\text {th }}, 60^{\text {th }}$ and $90^{\text {th }}$ day of the experiment it was equal to $0.16,0.15$ and 0.15 , respectively.

In the $3^{\text {rd }}$ test group the thickness ratio was equal to 0.16 at the beginning of the experiment; on the $30^{\text {th }}, 60^{\text {th }}$ and $90^{\text {th }}$ day of the experiment it was equal to $0.16,0.14$ and 0.14 , respectively. In the control group thickness ratio was 0.17 at the initial stage of the experiment; on the $30^{\text {th }}$, $60^{\text {th }}$ and $90^{\text {th }}$ day of the experiment it was equal to 0.18 , 0.15 and 0.13 , respectively (Table 4 ).

As compared to the control group, the thickness ratio on the $30^{\text {th }}$ day of the preparation application in the underyearlings of the $1^{\text {st }}, 2^{\text {nd }}$ and $3^{\text {rd }}$ test groups was lower by $0.9,0.8$ and $0.8 \%$, respectively. On the $60^{\text {th }}$ day of the experiment the thickness ratio in sturgeons of the $1^{\text {st }}$ and $2^{\text {nd }}$ test groups was equal to this value of the control group fish. According to our findings, the thickness ratio 
in the underyearlings of the $1^{\text {st }}, 2^{\text {nd }}$ and $3^{\text {rd }}$ test groups was higher than that of the control group analogs on the $90^{\text {th }}$ day of the experiment.

Analyzing the obtained data, it could be noted that the thickness ratio indicates the growth intensity in underyearlings and development of fish muscles. High values of the thickness ratio in the underyearlings of the test groups are indicative of their more intensive growth and development, as well as of fry survivability.

On the $6^{\text {th }}, 16^{\text {th }}, 26^{\text {th }}, 36^{\text {th }}, 46^{\text {th }}$ and $56^{\text {th }}$ day of the experiment the mass buildup factor in underyearlings of the $1^{\text {st }}$ test group was equal to $0.18 \pm 0.01,0.09 \pm 0.01$, $0.33 \pm 0.01, \quad 0.03 \pm 0.01, \quad 0.06 \pm 0.01$ and $0.24 \pm 0.01$, respectively.

On the $6^{\text {th }}, 16^{\text {th }}, 26^{\text {th }}, 36^{\text {th }}, 46^{\text {th }}$ and $56^{\text {th }}$ day of the experiment the mass buildup factor in underyearlings of the $2^{\text {nd }}$ test group made $0.15 \pm 0.01,0.09 \pm 0.0,0.36 \pm 0.01$, $0.03 \pm 0.01,0.09 \pm 0.01$ and $0.18 \pm 0.01$, respectively.

On the $6^{\text {th }}, 16^{\text {th }}, 26^{\text {th }}, 36^{\text {th }}, 46^{\text {th }}$ and $56^{\text {th }}$ day of the experiment the mass buildup factor in underyearlings of the $3^{\text {rd }}$ test group made $0.24 \pm 0.01,0.09 \pm 0.01,0.3 \pm 0.0$, $0.04 \pm 0.01,0.04 \pm 0.01$ and $0.12 \pm 0.01$, respectively.

On the $6^{\text {th }}, 16^{\text {th }}, 26^{\text {th }}, 36^{\text {th }}, 46^{\text {th }}$ and $56^{\text {th }}$ day of the experiment the mass buildup factor in the control group underyearlings amounted to $0.12 \pm 0.0 .1,0.1 \pm 0.01$, $0.23 \pm 0.01, \quad 0.06 \pm 0.01, \quad 0.06 \pm 0.01$ and $0.12 \pm 0.01$, respectively (Table 5).

According to our research data, the mass buildup factor in underyearlings of test groups varied with definite regularity (Table 5). A considerable increase in the mass buildup factor was recorded on the $6^{\text {th }}, 26^{\text {th }}$ and $56^{\text {th }}$ day of the experiment. On the $6^{\text {th }}$ day of research the cycle of daily preparation application was finished, on the $26^{\text {th }}$ day the preparation was ceased to be applied according to the feed schedule of 10 applications every other day, and on the $56^{\text {th }}$ day we completed using BS 225 preparation according to the feed schedule of 6 applications once per 5 days. In terms of the mass buildup, on the $6^{\text {th }}$ day of research the underyearlings of the $1^{\text {st }}, 2^{\text {nd }}$ and $3^{\text {rd }}$ test groups exceeded the control analogs by 50, 25 and $100 \%$, respectively. On the $26^{\text {th }}$ and $56^{\text {th }}$ day of the experiment this parameter in the underyearlings of the $1^{\text {st }}$ and $2^{\text {nd }}$ test groups was higher than that of the control analogs by 43.5 and $100 \% ; 56.5$ and $50.0 \%$, respectively; and by $30.4 \%$ in the $3^{\text {rd }}$ group only on the $26^{\text {th }}$ day. When feeding with the food supplement at a dosage of $15 \mathrm{mcl} / \mathrm{kg}$ fish mass this factor was lower than in the test groups on the $36^{\text {th }}$ and $46^{\text {th }}$ day, and on the $56^{\text {th }}$ day it was at the control group level.

The mass buildup factor is an important parameter in fish aquaculture, since it characterizes fish growth rate. Therefore, the studied microbiological preparation initiates sturgeon growth. The mass buildup values in the underyearlings of the test groups were higher during the preparation application period.

\section{Conclusions}

- Application of BS 225 microbiological preparation based on Bacilus Siamensis strains in sturgeon aquaculture has beneficial effect on the exterior features of fish. The extent and focus of action depended on the preparation dosage. BS 225 probiotic did not adversely affect sturgeon underyearlings at the applied dosage.

- Maximum increase in exterior features of the Acipenseridae underyearlings in the test groups (Fulton's condition factor, girth factor and thickness ratio), as compared to the control group, was recorded at the end of the experiment, on the $90^{\text {th }}$ day of research. Maximum increase in the fineness ratio was noticed on the $30^{\text {th }}$ day of the experiment when feeding with the preparation at a dosage of $10 \mathrm{mcl} / \mathrm{kg}$ fish mass.

- Values of the mass buildup factor varied depending on the dosage of BS 225 microbiological preparation. In the initial period of the preparation application on the $6^{\text {th }}$ day of the experiment the maximum values of the mass buildup factor were recorded in the $3^{\text {rd }}$ test group, where fish were fed with the microbiological supplement at a dosage of $15 \mathrm{mcl} / \mathrm{kg}$ fish mass. On the $26^{\text {th }}$ and, particularly, on the $56^{\text {th }}$ day of the experiment the mass buildup factor was higher than that of fish fed with the microbiological supplement at a dosage of $10 \mathrm{mcl} / \mathrm{kg}$ fish mass. Maximum increase in the mass buildup factor over the experimental period was recorded when using the preparation at a dosage of $10 \mathrm{mcl} / \mathrm{kg}$ fish mass.

- BS 225 microbiological preparation initiates sturgeon growth rate. Over the research period the optimal results were obtained when feeding the microbiological supplement at a dosage of $10 \mathrm{mcl} / \mathrm{kg}$ fish mass. Values of the mass buildup factor in underyearlings of the test groups were higher within the period of feeding with the preparation. During application of BS 225 microbiological preparation the sturgeons of the test groups had higher winter resistance and environmental resistance. 


\section{References}

1. Kesarcodi-Watson A, Kaspar HK, Lategan MJ, Gibson L. Probiotics in aquaculture: The need, principles and mechanisms of action and screening processes. Aquaculture. 2008; 274:1-14.

2. Nozdrin GA, Ivanova AB, Alikin YuS, et al. System of preparations for solving ichtyo-pathological problems in aquaculture. NSAU Bulletin. 2012; 2(23):62.

3. Ivanova AB, Sariev BT, Nozdrin GA, Moruzi IV, et al. Prospects of using bacterial preparations and probiotics in fish farming. NSAU Bulletin. 2012; 2(23):58-61.

4. Nozdrin GA, Ivanova AB, Shevchenko AI, et al. Scientific foundations for application of probiotics in poultry husbandry: Monograph. Novosibirsk: NSAU Press; 2005.

5. Nozdrin GA, Moruzi IV, Khmelkov SV, et al. Efficiency of Vetom 2.26 probiotic in feeding carp fry. NSAU Bulletin. 2013; 4(29):58-60.

6. Nozdrin GA, Fedotov YuN, Shevchenko SA, et al. Poultry efficiency index and quality of poultry products when applying probiotics of Vetom and Selena class: Monograph. Novosibirsk: NSAU Press; 2013.

7. Zoetendal EG, Vaughan EE, de Vos WM. A microbial world within us. Mol Microbiol. 2006; 59:1639-50.

8. Schiffrin E, Rochat F, et al. Immunomodulation of blood cells following the ingestion of lactic acid bacteria. J Dairy Sci. 2005; 78:491-7.
9. Shui W, Gilmore SA, Sheu L, Liu J, Keasling JD, Bertozzi CR. Quantitative proteomic profiling of host-pathogen interactions: The macrophage response to mycobacterium tuberculosis lipids. J Proteome Res. 2009; 8(1):282-9.

10. Mai V. Dietary modification of the intestinal microbiota. Nutr Rev. 2004; 62:235-42.

11. Khachatryan ZA, Ktsoyan ZA, Manukyan GP, et al. Predominant role of host genetics in controlling the composition of gut microbiota. PLoS ONE. 2008; 3(8):e3064.

12. Yukhimenko LN. Microbiocenosis of water and fish in aquarium husbandry, and factors affecting it. Proceedings of VI International Applied Research Conference Aquarium as a Means of Understanding the World; Moscow. 2010. P. 83-5.

13. Burlachenko IV, Banshchikova IV, Avetisov KB, Malik EV. Usage of probiotics at the early stages of fish development and their influence on the microflora, growth, and survivability of the Lena river sturgeon larvae (Acipenser Baerii). Moscow: VNIRO Publishing; 2006. p. 231-3.

14. Panasenko VV. Estimation of microbiological parameters of probiotics used in fish feed (Sublitis, Vetom, Subalin). Proceedings of the International Scientific Conference State and Development Perspectives of the Arid Zone Farm Fish Breeding; Rostov-on-Don: SSC RAS Press; 2006; p. 70-1. 